\title{
Antifungal of Fruit and Shoot Extracts of Orania palindan on Coriolus versicolor Growth
}

\author{
Endra Gunawan ${ }^{1}$ Yenni Yendri Salosa ${ }^{1}$ Julita T. Paladan ${ }^{1}$ Yuyu Rahayu ${ }^{1}$ \\ Edy Budiarso ${ }^{2}$ Enih Rosamah ${ }^{2}$ Enos Tangke Arung, ${ }^{2, *}$ \\ ${ }^{1}$ Forestry Faculty of Universitas Papua Manokwari, Jl. Gunung Salju Amban-Manokwari Papua Barat \\ ${ }^{2}$ Forestry Faculty Staff of Universitas Mulawarman East Kalimantan, Jl. Gunung Kelua Samarinda \\ *Corresponding author. Email: tangkearung@yahoo.com
}

\begin{abstract}
Orania palindan is a species of areca nut from Family Arecaceae that produces toxins, especially in its fruit and shoot. This research aimed to test the antifungal property of $O$. palindan fruit and shoot using hot water extraction on the growth of Coriolus versicolor. Complete randomized design was used with four extract concentrations $(0 \%, 2 \%, 4$ $\%$, and $6 \%$ ), each with three replications. Data were analyzed using Analysis of Variance (ANOVA) using SPSS. Results indicated that $O$. palindan fruit and shoot extracts significantly inhibited C. versicolor growth at $2 \%, 4 \%$, and $6 \%$. Duncan post-hoc test indicated that shoot extract at $6 \%$ concentration was the most effective at inhibiting C. Versicolor growth.
\end{abstract}

Keyword: Orania palindan, Antifungal, Coriolus versicolor

\section{INTRODUCTION}

Papua Island is one of the areas in Indonesia with tremendous biodiversity. Plants in Papua island are estimated to reach 20,000 to 25,000 species, so Papua island is known as a megadiversity. One of the flora in Papua is the Areca palm from the family of Palmae or Arecaceae. About 2,300 palm species globally, 1,000 species are in Malesiana, with 270 species found in Papua and Papua New Guinea [1,10].

Areca plant, one of the Arecaceae species, is commonly found in India, Malaysia, Taiwan, Indonesia, and other Asian countries [4,6]. One of the areca palm species that the Papuan community is not exploited is Orania because its shoot contains toxin [1]. A scientific investigation is needed to test the toxin of the Orania plant, learn about the antifungal property of its fruit and shoot with hot water solvent (1000C) on the growth of white root fungus (Coriolus versicolor).

\section{MATERIAL AND METHODS}

\subsection{Sample Preparation}

Fruit and shoot samples of $O$. palindan were taken from Demini village, Momiwaren District, South
Manokwari Regency, Papua Barat province. Samples were taken from two trees. The fruits and shoots were cut up to $\pm 0.5 \mathrm{~cm} \times 0.5 \mathrm{~cm} \times 0.5 \mathrm{~cm}$ and dried in an airconditioned room at $16-18 \mathrm{oC}$ until air-dry. Air-dry samples were grounded using a hammermill.

\subsection{Sample Extraction}

Five hundred grams of powder resulting from grinding using the hammermill was macerated using hot water $\left(100^{\circ} \mathrm{C}\right)$ with $1: 5$ powder to solvent ratio and was let cool for 24 hours. Filtrate extracted was then evaporated in an air-conditioned room at $16-180 \mathrm{C}$ aided by a fan to get a solid extract.

\subsection{Fungi Preparation}

Antifungal testing on wood-weathering fungi was done on white root fungus, $C$. versicolor. C. versicolor isolate was obtained from Tropical Silviculture and Forest Ecology Busgenweg Gottingen Germany in the form of culture in a petri dish. Before testing it in vitro, the fungus was first rejuvenated in a petri dish using PDA media. 


\subsection{Statistical Analysis}

A complete randomized design was used in this experiment with four treatments $(0 \%, 2 \%, 4 \%$, and $6 \%)$, each with three replications. The response variable measured in this study was $C$. versicolor growth and the Average Activity of Anti Fungi (AAF) treated with $O$. palindan fruit and shoot extracts with concentrations of $2 \%, 4 \%$ and $6 \%$. The $\mathrm{C}$. versicolor growth treated with $O$. palindan fruit and shoot extracts with concentrations of $2 \%, 4 \%$ and $6 \%$, which refers to the American Wood Preserve Association (Standard No. M10-63). The growth of $C$. versicolor was calculated using the following equation:

$$
\operatorname{Pc}(\%)=\frac{\mathrm{LPc}}{\mathrm{Lc}} \times 100
$$

Where:

$\mathrm{Pc}=$ Percentage of petri dish area covered with hypha $(\%)$

LPc $=$ Total area covered by fungi $\left(\mathrm{cm}^{2}\right)$

$\mathrm{Lc}=$ Total area of the petri dish $\left(\mathrm{cm}^{2}\right)$

The total area covered by fungi (LPc) on a petri dish with a $9 \mathrm{~cm}$ diameter was calculated using the following equation:

$$
\mathrm{LPc}=\frac{1}{4} \pi \mathrm{D}^{2}
$$

LPc $=$ Total area covered by fungi $\left(\mathrm{cm}^{2}\right)$

$\Pi=3.14$

$\mathrm{D}=$ Diameter of the distribution of hypha

The Average Activity of Anti Fungi (AFA), which refers to $[3,4]$, calculated using the following equation:

$\mathrm{I}=[(\mathrm{C}-\mathrm{T}) / \mathrm{C}] \mathrm{x} 100$

Where:

$\mathrm{I}=$ inhibition $(\%)$

$\mathrm{C}=$ colony diameter of mycelium from control Petri dish $(\mathrm{mm})$

$\mathrm{T}=$ colony diameter of mycelium from the Petri dish containing the solutions $(\mathrm{mm})$

Analysis of chemical component of extraction using LCMS was conducted at Indonesian Police Headsquare Forensic Laboratory Centre (Puslabfor), Jakarta.

\subsection{Data Analysis}

Data was analyzed by variance analysis (ANOVA). If the result was significant, Duncan posthoc test was conducted. Data analysis was performed using SPSS 25 for windows application.

\section{RESULT AND DISCUSSION}

\subsection{Test of Antifungal Activity of Fruit and Shoot Extract of Orania palindan}

Antifungal is a compound used to treat infectious diseases caused by fungi. Antifungal testing showed that fruit and shoot extract of $O$. palindan at concentration $2 \%, 4 \%$ and $6 \%$ were able to inhibit the growth of $C$. versicolor fungi (Figure 1 and 2).

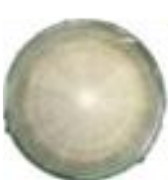

(a)

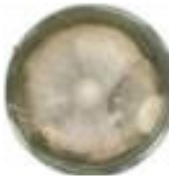

(b)

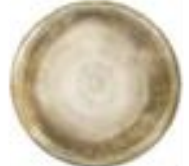

(c)

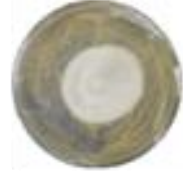

(d)
Figure 1 Inhibition activity of Orania palindan fruit extract on growth of Coriolus versicolor on day 7:(a) Control, (b) 2\%, (c) $4 \%$, and (d) $6 \%$ concentrations

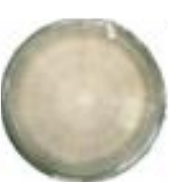

(a)

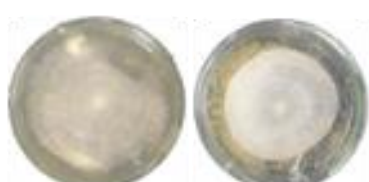

(b)

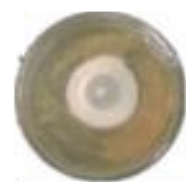

(d)
Figure 2 Inhibition activity of Orania palindan shoot extract on growth of Coriolus versicolor on day 7: (a) Control, (b) 2\%, (c) $4 \%$, and (d) $6 \%$ concentrations

As many researchers have found, $C$. versicolor is more resistant to antifungal treatment than other fungi. $C$. versicolor was more able to maintain its growth compared to Schizophyllum commune when treated clove-leaf extracts [2]. C. versicolor could support mycelium growth by up to $40 \%$, while Schizophyllum commune only $30 \%$ [12]. The percentage of wood weight reduction due to $C$. versicolor attack was more significant than other fungi, which reached $15.23 \%$ [13]. C. versicolor was chosen in this study because of its known resistance.

The average percentage of $C$. versicolor growth of control was $100 \%$, reached on the 7 th day. The average percentages of $C$. versicolor growth treated with $2 \%$, $4 \%$, and $6 \%$ concentrations of $O$. palindan fruit extracts were $60.49 \%, 50.5 \%$, and $31.73 \%$, respectively. The average percentages of $\mathrm{C}$. versicolor growth were $70.00 \%, 54.92 \%$, and $24.67 \%$ when treated at $2 \%, 4 \%$, and $6 \%$ concentrations with the shoot extract. Overall, the lowest average growth of $C$. versicolor was obtained in the treatment using shoot extract at a $6 \%$ concentration (Figure 3). 


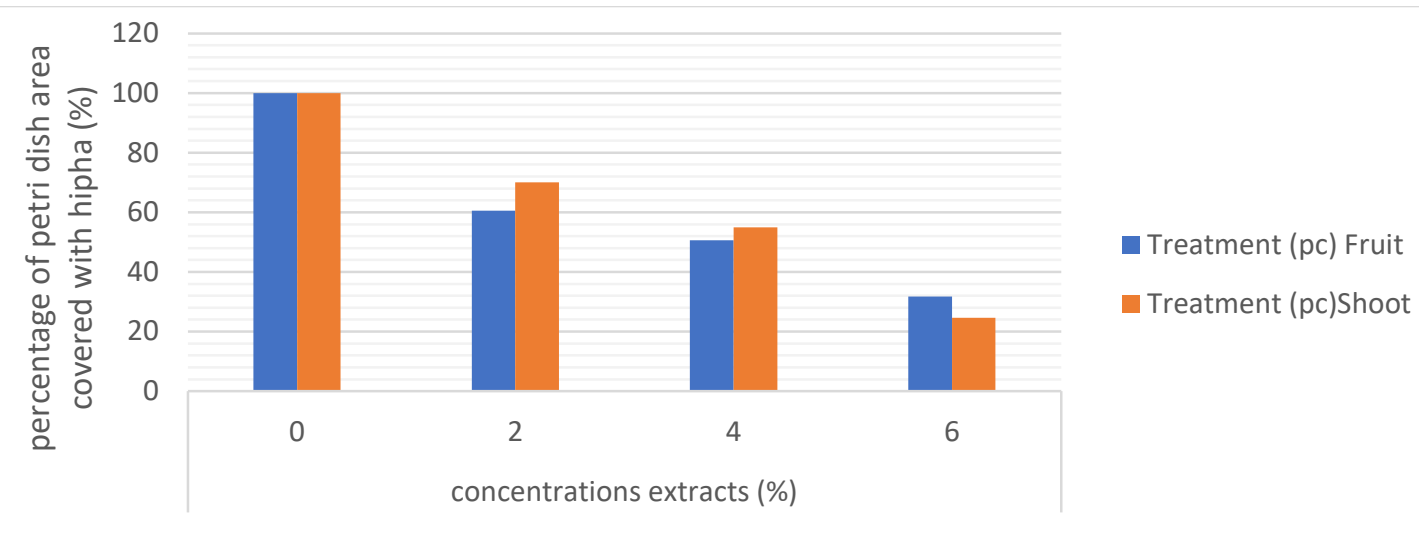

Figure 3 The average percentages of petri dish area covered by $C$. versicolor hypha $(\mathrm{Pc})$ on different treatments

ANOVA test at $95 \%$ confidence level $(a=0,05)$ indicated that $2 \%, 4 \%$, and $6 \%$ of $O$. palindan fruit extract significantly affected the growth of $C$. versicolor. At $95 \%$ confidence level, Duncan test on the effect of $O$. palindan fruit extracts indicated that the $2 \%$, $4 \%$, and $6 \%$ treatments did not differ significantly, but all were very different from control $(0 \%$; Table 1$)$.

Table 1. Duncan test on the effect of Orania palindan fruit extract treatments on the growth of Coriolus versicolor ( $\mathrm{N}$ refers to the number of replicates)

\begin{tabular}{|c|c|c|c|}
\hline \multirow{2}{*}{ Treatment (\%) } & \multirow{2}{*}{$\mathrm{N}$} & \multicolumn{2}{|c|}{ Subset $(\mathrm{a}=0,05)$} \\
\cline { 3 - 4 } & & 1 & 2 \\
\hline 6 & 3 & 32.92 & \\
\hline 4 & 3 & 51.26 & \\
\hline 2 & 3 & 61.77 & \\
\hline 0 & 3 & & 100.00 \\
\hline Signification & & 0.054 & 1.000 \\
\hline
\end{tabular}

At $95 \%$ confidence level, Duncan test on the effect of $O$. palindan shoot extracts indicated the $2 \%$ treatment was different from $0 \%$ and $6 \%$ treatments but not separate from the $4 \%$ treatment. It also showed that the $0 \%$ treatment differ from the $2 \%, 4 \%$ and $6 \%$ treatments and that the $6 \%$ treatment had the lowest mycelium growth (Table 2).
Table 2. Results of Duncan test on the effect of Orania palindan hot extract treatments on the growth of Coriolus versicolor ( $\mathrm{N}$ refers to the number of replicates)

\begin{tabular}{|c|c|c|c|c|}
\hline \multirow{2}{*}{$\begin{array}{c}\text { Treatment } \\
(\%)\end{array}$} & \multirow{2}{*}{$\mathrm{N}$} & \multicolumn{3}{|c|}{ Subset $(\mathrm{a}=0,05)$} \\
\hline & & 1 & 2 & 3 \\
\hline 6 & 3 & 24.97 & & \\
\hline 4 & 3 & & 55.41 & \\
\hline 2 & 3 & & 71.06 & \\
\hline 0 & 3 & & & 100.00 \\
\hline Signification & & 1.000 & 0.174 & 1.000 \\
\hline
\end{tabular}

Fruit and shoot extracts of $O$. palindan were able to inhibit the growth of $C$. versicolor. The greater the extract used, the smaller the percentage of petri dish area covered with hypha. As indicated by the Duncan test results, the $2 \%$ extract could inhibit $C$. versicolor, but the most effective at inhibiting growth was $O$. palindan shoot extract at $6 \%$ concentration.

Cinnamomum camphora extract can be developed as a natural wood preservative [7] So, the extract of the fruit and shoot extracts of $O$. palindan can also be developed as one.

\subsection{Activity Result of Antifungal (AFA) Score Test}

Result of the AFA calculation, shown in Table 3.

Table 3. Percentage Average score of (Activity of Anti Fungi=AFA)

\begin{tabular}{|c|c|c|c|}
\hline $\begin{array}{c}\text { Part of } \\
\text { Section }\end{array}$ & $\begin{array}{c}\text { Concentra tion } \\
(\%)\end{array}$ & AFA & $\begin{array}{c}\text { Degree of } \\
\text { Activities }\end{array}$ \\
\hline \multirow{3}{*}{ Fruit } & 0 & 0.00 & not active (-) \\
\cline { 2 - 4 } & 2 & 39.51 & moderate (++) \\
\cline { 2 - 4 } & 4 & 49.43 & moderate (++) \\
\cline { 2 - 4 } Shoot & 6 & 68.27 & strong (+++) \\
\cline { 2 - 4 } & 0 & 0.00 & not active (-) \\
\cline { 2 - 4 } & 2 & 30.00 & moderate (++) \\
\cline { 2 - 4 } & 4 & 45.08 & moderate (++) \\
\hline \multirow{3}{*}{} & 6 & 75.33 & strong (+++) \\
\hline
\end{tabular}

Source: Primary data after processed 


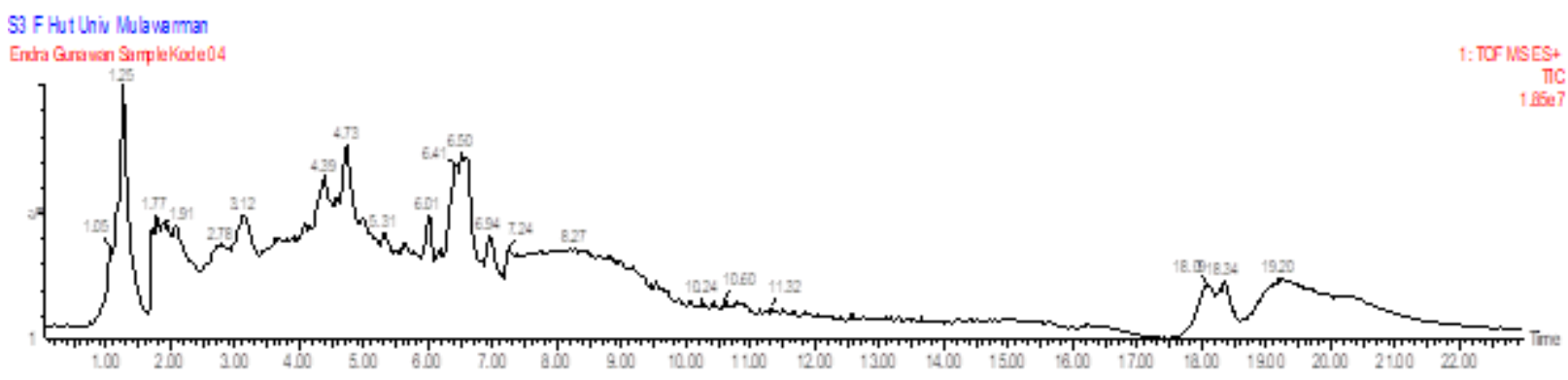

Figure 4 The Result of LCMS Analysis of Orania palindan Shoot's Extract using Hot Water Solvents

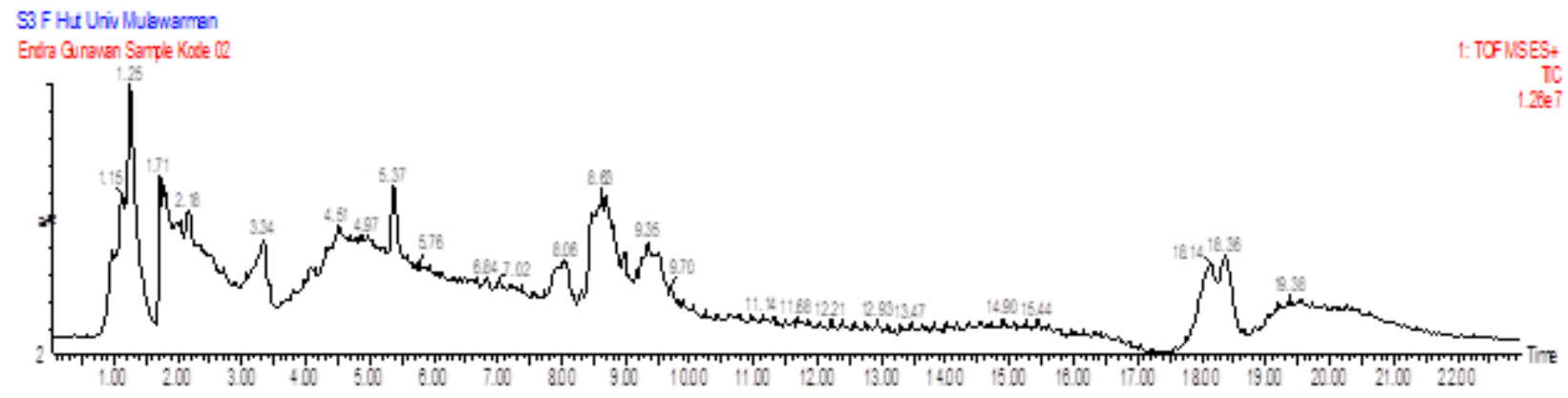

Figure 5 The Result of LCMS Analysis of Orania palindan Fruit's Extract using Hot Water Solvent

At the extraction of fruit and shoot of $O$. palindan using hot water, at concentration $2 \%, 4 \%$, the resulting moderat and $6 \%$ resulted in a strong AFA score. $C$. versicolor is strong fungi but can be inhibited its mycelium growth by diluting the extract of fruit and shoot of $O$. palindan in hot water.

\subsection{LCMS Analysis}

The LCMS analysis of O. palindan shoot's and fruit extract extracted using hots water solvents shows in Figure 4 and 5. The LCMS analysis of $O$. palindan shoots, and fruit extract using hot water solvent resulted in 11 chemical compounds that can be antifungal. These compounds are listed in Table 4. At the same time, the fruit's extract contains six compounds, as the list in Table 5.
Table 4. List of The Chemical Compounds of Orania palindan Shoot's Extract extracted Using Hot Water Solvents

\begin{tabular}{|c|l|}
\hline No. & \multicolumn{1}{|c|}{ Name of compound } \\
\hline 1. & $\begin{array}{l}\text { 5-Aminotetrazolo[1,5-a]pyrazine-6,8- } \\
\text { dicarbonitrile }\end{array}$ \\
\hline 2. & $\begin{array}{l}\text { 1-Acetoxy-5-fluoro-3-(2-oxiranylmethyl)- } \\
2,4(1 \mathrm{H}, 3 \mathrm{H}) \text {-pyrimidinedione; }\end{array}$ \\
\hline 3. & $\begin{array}{l}\text { 5-Chloro-4-(chloromethyl)-1-(4-fluorobenzyl)-3- } \\
\text { isopropyl-1H-pyrazole }\end{array}$ \\
\hline 4. & $\begin{array}{l}3-(5-B r o m o-2-t h i e n y l)-6-m e t h y l \\
{[1,2,4] \text { triazolo[3,4-b][1,3,4]thiadiazole }}\end{array}$ \\
\hline 5. & $\begin{array}{l}1-\{(2 \mathrm{~S}, 4 \mathrm{~S})-4-\text { Fluoro-1-[(5-methyl-1,2,4- } \\
\text { oxadiazol-3-yl)methyl]-2-pyrrolidinyl\}-N- } \\
\text { methylmethanamine dihydrochloride }\end{array}$ \\
\hline 6. & $\begin{array}{l}\text { N-\{2-[(5-Bromo-1,3,4-thiadiazol-2-yl) amino] } \\
\text { ethyl\} methanesulfonamide }\end{array}$ \\
\hline 7. & $\begin{array}{l}3,3 \text {-(1-Methyl-1H-1,2,4-triazole-3,5-diyl)bis(4- } \\
\text { azido-1,2,5-oxadiazole) }\end{array}$ \\
\hline 8. & $\begin{array}{l}\text { 3-(2,6-Dichlorophenyl)-N-(4-fluoro-3- } \\
\text { nitrophenyl)-5-methyl-1,2-oxazole-4- } \\
\text { carboxamide; }\end{array}$ \\
\hline 9. & 2-Oxo-2H-imidazole-4,5-dicarbonitrile \\
\hline 10. & $\begin{array}{l}\text { 3,6-Dihydro-1H-[1,2,5]oxadiazolo[3,4- } \\
\text { b][1,2,3]triazolo[4,5-e]pyrazine; }\end{array}$ \\
\hline 11. & $\begin{array}{l}2,2-\text { Dihydroxy-1,3,5,7-tetraoxa-2-silaspiro } \\
\text { [3.3]heptan-6-one, }\end{array}$ \\
\hline
\end{tabular}


Table 5. The Chemical Compounds of Orania palindan Fruit's Extract extracted Using Hot Water Solvents

\begin{tabular}{|c|c|}
\hline No. & Name of compound \\
\hline 1. & $\begin{array}{l}\text { 3-(4-(bromomethyl) phenyl)-5-methyl-1,2,4- } \\
\text { oxadiazole }\end{array}$ \\
\hline 2. & $\begin{array}{l}\text { N-(5-Nitro-3,8-dioxido[1,2,5]oxadiazolo[3,4- } \\
\text { e][2,1,3]benzoxadiazol-4-yl) }\end{array}$ \\
\hline 3. & $\begin{array}{l}\text { Ammonium 2-(dinitromethyl)-5-nitro-2,5- } \\
\text { dihydro-1H-tetrazole-5-carboxylate }\end{array}$ \\
\hline 4. & $\begin{array}{l}\text { 2-[3-(Trimethylammonio)propyl]-1,2,3,4- } \\
\text { tetrahydro isoquinolinium dibromide }\end{array}$ \\
\hline 5. & $\begin{array}{l}\text { Dipropyl [5-(2,4-dichlorophenyl)-1,3,4- } \\
\text { oxadiazol-2-yl] phosphoramidate }\end{array}$ \\
\hline 6. & $\begin{array}{l}\text { [(4,6-Dichloro-1,3,5-triazin-2-yl)(4- } \\
\text { methoxyphenyl) carbamoyl] sulfamic acid. }\end{array}$ \\
\hline
\end{tabular}

The result of LCMS analysis shows that from the extract of fruit and shoot of $O$. palindan extracted using hot water, the compounds that become anti fungi are azole and pirimidin groups. Azole group in the extract of fruit and shoot of $O$. palindan is consist of tetrazole, pyrazole, thiadiazole, oxazole, and imidiazole. Tetrazole is a compound that acts as an anti-inflammatory, antibacteria, antivirus, anti-tuberculosis, anti-fungi, analgesic, and antitumor [3]. Derivation of triazole and thiadiazole are compounds that can be used as antibacteria and anti-fungi [9]. Imidazole compound contains purine, histamine, histidine, dan nucleic acid. Moreover, it is stated that the imidazole compound acts as anti-bacterial, anti-cancer, anti-tuberculosis, antifungi, analgesic, and anti-HIV [14]. Derivations of pyrimidine, such as furo [2,3-d] pyrimidine, triazolo [1, 5-a] pyrimidine, and tetrazole [1,5] pyrimidine, are compounds that act as anti-cancer, antivirus, antihypertension, analgesic, antipyretic, anti-inflammatory, anti-fungi, anti-bacteria, and anti-psoriasis [11].

\section{CONCLUSIONS}

Fruit and shoot extract of $O$. palindan can inhibit the growth of $C$. versicolor fungus. The most effective treatment to inhibit the growth of $C$. versicolor fungus is fruit and shoot extracts at $6 \%$ concentration. The part of $O$. palindan plant that was most effective at inhibiting the growth of $C$. versicolor fungus was the shoot. ANOVA results showed that the fruit and shoot extracts of $O$. palindan had a significant effect on the growth of C. versicolor fungi. Duncan test results showed that the $4 \%$ concentration of fruits and shoot extract inhibited the growth of $C$. versicolor, but the most effective concentration was the shoot extract at $6 \%$ concentration. The anti-fungi compounds from the extract of fruit and shoot of $O$. palindan using hot water Solvent are azole and pyrimidine. Azole group consist of tetrazole, pyrazole, thiadiazole, oxazole, and imidiazole.

\section{ACKNOWLEDGMENT}

The authors would like to thank Mr Yosias Gandhi, who has assisted in the culture of $C$. versicolor from Gottingen University and $\mathrm{Mr}$ Azhar Dahlan, Staff of Police Forensic Laboratory in Jakarta, who has helped carry out the LCMS $O$. palindan extract.

\section{REFERENCES}

[1] W.J. Baker, J. Dransfield, Palem New Guinea, Royal Botanic Garden, KEW, 2006.

[2] N. Etikawati, S. Listyawati, Pertumbuhan Coriolus versicolor dan Schizophyllum commune pada Media yang Mengandung Oleum Caryophylli. BioSMART, 1(1), 1999, pp. 22-30. http://biosmart.mipa.uns.ac.id/index.php/biosmart/a rticle/download/47/20

[3] W. El-Sayed, R.E.A. Megeid, H.A.S. Abbas, Synthesis and Anti-microbial Activity of New 1 [(tetrazol-5-yl) methyl] indole Derivates, theirs 1,2,4-trizole Thioglycosides and Acylic Analogs, Archives of Pharmacal Research, 2010, pp. 108510996. DOI 10.1007/s12272-011-0706-y

[4] P. Jaiswal, P. Kumar, V.K. Singh, D.K. Siggh, Areca catechu L.: A Valuable Herbal Medicine Against Different Health Problems. Journal of Medicinal Plant, 5(2), 2011, pp. 145-152. DOI: $10.3923 /$ rjmp.2011.145.152

[5] S.N. Kartal, E. Terzi, T. Yoshimura, R. Arango, C.A. Clausen, F. Green, Preliminary Evaluation of Storax and Its Constituensts: Fungal Decay, Mold and Termite Resistance, Journal Elsevier, 2012, pp.

47-54. https://doi.org/10.1016/j.ibiod.2012.02.002

[6] A.P. Keim, J. Dranfield, A Monograph of the Genus Orania (Arecaceae: Oranieae), Jurnal KEW Bulletin, 67(1), 2012, pp. 127-190. https://link.springer.com/article/10.1007/s12225012-9356-6

[7] Q. Li, X. Wang, J. Lin, J. Liu, J. Mao-sheng, L. L. Chu, Chemical Composition and Antifungal Activity of Extracts from the Xylem of Cinnamomum camphora, 2014. DOI:10.15376/BIORES.9.2.2560-2571

[8] O. Özgenc, S. Durmaz, U.C. Yildiz, E. Erisir, A Comparison Between Some Bark Extracts: Antifungal Activity, Journal of Forestry Faculty. Kastamonu University, 2017, pp. 502-508. DOI: $10.17475 /$ kastorman.282637

[9] G.K. Patel, H.S. Patel, Synthesis, Spectroscopic and Biological Activity of 3-(Pyridin-4-yl)-[1,2,4] Triazolo[1,3,4][Thiadiazole] derivates, Pelagia 
Research Library, 2015. https://www.imedpub.com/articles

[10] Y.Y. Rahawarin, Eksplorasi Spesies Palem di Pulau Mioswaar, Kabupaten Teluk Wondama, Irian Jaya Barat (Papua), Jurnal Biodiversitas, 6(2), 2005, pp. 108-112.

[11] M.A. Salem, M.I. Marazouk, N.F. Mahmoud, Synthesis of Various Fused Pyrimidine Rings and Their Pharmacological and Anti-microbial Evaluation, Journal of Serbian Chemical Society, 2014, 2014, pp. 1059-1073. https://www.shd.org.rs/JSCS.

[12] S. Sunarto, S. Lisyawati, N. Etikawati, A. Susilowati, Aktivitas Antifungi Ekstrak Daun dan Bunga Cengkeh (Syzigium aromaticum L) pada Pertumbuhan Cendawan Perusak Kayu, Biosmart, 2(1), 1999, pp. 20-27.

[13] S. Sihati, Ketahanan Kayu Mangium (Acacia mangium Willd.) terhadap Sebelas Jamur Pelapuk Kayu, Buletin Penelitian Hasil Hutan, 20(3), 2002, pp. 187-193. http://ejournal.fordamof.org/ejournal-litbang/index.php/JPHH/article

[14] A. Verma, S. Joshi, D. Singh, Imidazole: Having Versatile Biological Activities, Journal of Chemistry, 2013. https://doi.org/10.1155/2013/329412 